\title{
The Interaction of Strain of Holstein-Friesian Cows and Pasture-Based Feed Systems on Milk Yield, Body Weight, and Body Condition Score
}

\author{
B. Horan, ${ }^{1,2}$ P. Dillon, ${ }^{1}$ P. Faverdin, ${ }^{3}$ L. Delaby, ${ }^{3}$ F. Buckley, ${ }^{1}$ and M. Rath ${ }^{2}$ \\ ${ }^{1}$ Dairy Production Department, Teagasc, Dairy Production Research Centre Moorepark, Fermoy, Co. Cork, Ireland \\ ${ }^{2}$ Department of Animal Science, Faculty of Agriculture, University College Dublin, Belfield, Ireland \\ ${ }^{3}$ 3INRA, UMR Production du Lait, 35590 St Gilles, France
}

\section{ABSTRACT}

Interactions between genotype and environment are becoming increasingly important as cattle genotypes are being managed in a diverse range of environments worldwide. The objective of this study was to investigate if there is an interaction of strain of HolsteinFriesian cows (HF) by grass-based feed system that affects milk production, body weight, and body condition score. Three strains of HF were compared on 3 pasture-based feed systems over 3 consecutive years. The 3 strains of HF were: high production North American, high durability North American, and New Zealand. The 3 grass-based feeding systems (FS) were: a high grass allowance system (MPFS), a high concentrate system (HCFS), and a high stocking rate system (HSFS). There was a separate farmlet for each FS and a total of 99,117 , and 117 animals were used in yr 1, 2, and 3 respectively, divided equally between strains of $\mathrm{HF}$ and FS. The high production cows produced the highest yield of milk, the New Zealand the lowest, and the high durability animals were intermediate. Milk fat and protein content were higher for the New Zealand strain than for the high production and high durability strains. The New Zealand strain had the lowest body weight and the highest condition score, whereas the high durability strain had the highest body weight, and the high production strain had the lowest condition score. There was a strain $\times$ FS interaction for yield of milk, fat, and protein. The milk production response to increased concentrate supplementation (MPFS vs. HCFS) was greater with both the high production and high durability strains $(1.10 \mathrm{~kg}$ of milk/ $\mathrm{kg}$ of concentrate for high production; $1.00 \mathrm{~kg}$ of milk/kg of concentrate for high durability) than the New Zealand strain $(0.55 \mathrm{~kg}$ of milk/kg of concentrate). The results indicate that the optimum strain of HF will vary with feed system.

Received August 20, 2004

Accepted November 19, 2004.

Corresponding author: B. Horan; e-mail: bhoran@moorepark. teagasc.ie.
(Key words: Holstein-Friesian strain, grass-based feed system)

Abbreviation key: $\mathbf{F S}=$ feed system, HCFS = high concentrate feed system, HD = high durability, $\mathbf{H F}=$ Holstein-Friesian, HP = high production, HSFS = high stocking rate feed system, MPFS = high grass feed system, NZ = New Zealand, PGSSH = postgrazing sward surface height.

\section{INTRODUCTION}

Milk production in Ireland is primarily based on seasonal-calving pasture-based systems. Because grazed grass is the lowest cost feed available, the objective of the system is to optimize the use of grazed grass in the diet of the lactating dairy cow (Dillon et al., 1995). This is best achieved by synchronizing calving date to the start of the grass-growing season, thereby achieving a long grazing season (February to late November) on predominantly grazed grass. The optimization of this system will greatly depend on a dairy cow that can efficiently convert this grass to a high quality milk product and is well adapted to a predominantly pasturebased seasonal-calving system.

Up to the mid1980s, the predominant breed of dairy cow in Ireland was the British Friesian. In Ireland over the last $20 \mathrm{yr}$, the use of North American HolsteinFriesian (HF) genetics has dominated, increasing from 9\% in 1990 to $65 \%$ in 2001 (Evans et al., 2004). These animals have been aggressively selected for high milk production in a predominantly confinement environment (Rauw et al., 1998). The popularity of the North American HF was most likely due to its increased productivity over dairy breeds in a market that rewarded for milk volume with lesser incentive for milk solids content. However, aggressive genetic improvement within the North American HF for increased milk yield has resulted in a now well-documented negative effect on cow fertility (Pryce and Veerkamp, 2001). There is a known antagonistic genetic relationship between milk yield and reproductive traits (Evans et al., 2002; Berry et al., 2003). Pryce et al. (1998) estimated an increase of the calving interval by 5 to $10 \mathrm{~d}$ per $1000 \mathrm{~kg}$ of 
additional milk yield when selecting for milk yield only. These values are supported by the results from controlled experiments comparing genetic groups across feeding systems (Buckley et al., 2000; Kennedy et al., 2002).

In contrast, the New Zealand HF has been selected for milk production, feed efficiency, and survivability on a predominantly grass-based diet with very limited concentrate supplementation (Harris and Kolver, 2001). In New Zealand, the North American HF cows are of higher BW, produce more milk volume and protein yield, and have lower concentrations of milk fat and protein than the New Zealand HF (Harris and Kolver, 2001).

It has until recently been widely assumed that if a strain is the best for one environment (e.g., confinement), it will also be the best in all other environments. Although previous studies, across a relatively narrow range of genetic merit and/or feeding systems, have failed to show a genotype $\times$ feed system $($ FS $)$ interaction, there is now evidence that high merit North American HF cows may be unable to express their full genetic potential when in a grass-based system of milk production (Kennedy et al., 2002). The importance of interactions between genotype and environment are substantial considering the diverse range of environments worldwide in which animals are now being managed.

The objective of the current study was therefore to investigate the effects of 3 strains of $\mathrm{HF}$ and 3 grassbased feed systems and their interactions on the milk production, BW, and BCS within Irish pasture-based systems of milk production.

\section{MATERIALS AND METHODS}

This study was carried out at Moorepark Research Centre in the Republic of Ireland over a 3-yr period (2001 to 2003).

\section{Animals}

Three strains of HF cow were compared: high production North American (HP), high durability North American (HD), and New Zealand (NZ). The mean pedigree index for each strain is displayed in Table 1 . The pedigree index for each cow was calculated as $0.50 \times$ sire predicted difference $+0.25 \times$ maternal grandsire predicted difference $+0.125 \times$ maternal great-grandsire predicted difference. The predicted difference of the sires and maternal grandsires were from the February 2004 international evaluations of the INTERBULL Animal Center (Uppsala, Sweden) using the technique known as MACE (multiple-trait across-country evaluation).
To create the HP strain, the top $50 \%$ of HF cows in the Moorepark herd (based on pedigree index for milk production) were inseminated with semen from 5 North American HF sires. The 5 sires chosen were the 5 highest sires available in Ireland at the time based on their relative breeding index; this was the index used in Ireland based on combined predicted difference for milk, fat, and protein yields, and protein content (Irish Cattle Breeding Statistics, 1999). Therefore the HP strain was selected to illustrate what would happen if Irish dairy farmers continued to select animals aggressively for increased milk production. The average proportion of North American HF genes in the HP strain was 90\%, with the remaining genes being British Friesian. To create the HD strain, the bottom $50 \%$ of HF cows in the Moorepark herds (based on pedigree index for milk production) were inseminated with semen from 5 North American HF sires, chosen on a combination of their pedigree indices for milk production, fertility, and linear (muscularity) traits. The dams used to generate this strain were representative of the $\mathrm{HF}$ cow that existed on most Irish dairy farms at the time. Therefore the HD strain was generated to represent a more balanced breeding policy including some indicators/fertility traits, as well as milk production traits. The average proportion of North American HF genes in the HD strain was $80 \%$, with the remaining genes being British Friesian. The NZ animals were imported as embryos from New Zealand and implanted into 13-mo-old HF heifers at Moorepark. The NZ embryos were generated by mating high genetic merit New Zealand HF cows (expressed in the New Zealand genetic evaluation system, Breeding Worth) with 5 high genetic merit New Zealand HF sires. On average, $87.5 \%$ of the NZ strain genes were of New Zealand HF ancestry. Jersey genes contributed a maximum of $12.5 \%$, with the remaining genes being of North American HF ancestry. The NZ strain represents a Holstein-Friesian strain that was selected within a pasture-based seasonal system, using an index that combined milk production and other traits of economic importance. The sires and dams used to generate each strain were representative of the top $10 \%$ of animals within their respective countries on overall genetic merit. The 3 strains were created not to be representative of any given existing strain of $\mathrm{HF}$ but merely to represent the consequences of various selection strategies on subsequent animal performance in pasture-based systems.

A total of 99, 117, and 117 animals were used in yr 1,2 , and 3 , respectively, divided equally between strains of $\mathrm{HF}$ and FS. The number of animals of each strain of HF and FS over the $3 \mathrm{yr}$ of the study is displayed in Table 2. In 2001, all 99 cows were $3 \mathrm{yr}$ old; in 2002, 45 animals were 3 yr old and 72 were parity 
Table 1. The mean pedigree index for 3 strains of Holstein-Friesian cows studied based on their predicted differences ${ }^{1}$ (and SD) for milk production, survival, and calving interval.

\begin{tabular}{lccc}
\hline Strain & High production & High durability & New Zealand \\
\hline Milk $(\mathrm{kg})$ & $+194(90.8)$ & $+76(61.4)$ & $+52(56.0)$ \\
Fat $(\mathrm{kg})$ & $+9.0(2.96)$ & $+6.3(2.84)$ & $+8.6(2.66)$ \\
Protein $(\mathrm{kg})$ & $+8.8(2.39)$ & $+5.7(1.58)$ & $+4.2(1.33)$ \\
Fat $(\mathrm{g} / \mathrm{kg})$ & $+0.3(0.53)$ & $+0.7(0.56)$ & $+1.3(0.58)$ \\
Protein $(\mathrm{g} / \mathrm{kg})$ & $+0.4(0.23)$ & $+0.6(0.30)$ & $+0.5(0.21)$ \\
Survival $(\%)$ & $-0.5(1.11)$ & $+0.4(0.51)$ & $+1.2(0.62)$ \\
Calving interval (d) & $+0.44(1.57)$ & $-1.2(0.71)$ & $-1.6(0.86)$ \\
\hline
\end{tabular}

${ }^{1}$ All predicted differences were obtained from the February 2004 international evaluations of the INTERBULL Animal Centre (Uppsala, Sweden) using the MACE (multi-trait across-country evaluation). The predicted difference for each cow was calculated as $0.50 \times$ sire predicted difference $+0.25 \times$ maternal grand sire predicted difference $+0.125 \times$ maternal great grand sire predicted difference.

2; and in 2003, 9 animals were 3 yr old, 45 were parity 2 , and 63 were parity 3 . Fifty-nine animals remained in the same FS for the duration of the study ( $3 \mathrm{yr})$. All primiparous cows were on a similar feeding regimen for the first 4 wk of lactation. Animals were selected within strain into groups of 3 , on the basis of calving date, milk production in the first $4 \mathrm{wk}$ of lactation, and BW, and then randomly assigned to 1 of 3 systems. Once allocated, animals were retained on the same FS in subsequent lactations.

\section{Feed Systems}

There was a separate farmlet for each of the 3 systems of production. The 3 systems compared were: a high grass allowance FS typical of spring-calving herds in Ireland (MPFS, control); a higher concentrate system FS (HCFS), and a higher stocking rate system (HSFS). Approximately 1.0 tonne of grass silage DM per cow was required during the housing period. The MPFS had an overall stocking rate of 2.47 cows/ha, $\mathrm{N}$ fertilizer input of $290 \mathrm{~kg}$ of N/ha (from early January to late September) and received $368 \mathrm{~kg}$ of concentrate per cow in early lactation with the remainder of the diet coming

Table 2. The number of dairy cow records included in the 3-yr analysis.

\begin{tabular}{|c|c|c|c|c|c|c|}
\hline \multirow[b]{2}{*}{ Group } & \multicolumn{3}{|c|}{ Strain of Holstein-Friesian ${ }^{1}$} & \multicolumn{3}{|c|}{ Feed system ${ }^{2}$} \\
\hline & HP & HD & $\mathrm{NZ}$ & MP & HS & $\mathrm{HC}$ \\
\hline \multicolumn{7}{|c|}{ No. of animals } \\
\hline Yr 1 & 33 & 33 & 33 & 33 & 33 & 33 \\
\hline Yr 2 & 39 & 39 & 39 & 39 & 39 & 39 \\
\hline Yr 3 & 39 & 39 & 39 & 39 & 39 & 39 \\
\hline \multicolumn{7}{|c|}{ No. of lactation records } \\
\hline Parity 1 & 51 & 51 & 51 & 51 & 51 & 51 \\
\hline Parity 2 & 39 & 39 & 39 & 39 & 39 & 39 \\
\hline Parity 3 & 21 & 21 & 21 & 21 & 21 & 21 \\
\hline
\end{tabular}

${ }^{1} \mathrm{HP}=$ High production; HD = high durability; NZ = New Zealand.

${ }^{2} \mathrm{MP}=$ High grass feed system; HS = high stocking rate feed system; $\mathrm{HC}=$ high concentrate feed system. from grazed grass. The HCFS had a similar overall stocking rate and $\mathrm{N}$ input as the MPFS but a concentrate input of $1452 \mathrm{~kg} / \mathrm{cow}$. The HSFS group had similar concentrate $(364 \mathrm{~kg} / \mathrm{cow})$ and $\mathrm{N}$ inputs as the MPFS but at a higher overall stocking rate of 2.74 cows/ha. The ingredient composition of the concentrate feed (kg/ tonne as fed) was as follows: $250 \mathrm{~kg}$ of barley, $260 \mathrm{~kg}$ of corn gluten, $350 \mathrm{~kg}$ of beet pulp, $110 \mathrm{~kg}$ of soybean meal, and $30 \mathrm{~kg}$ of minerals plus vitamins. The MPFS and HCFS were designed to allow each strain to express its potential within each FS largely unrestricted by limitations in feed supply. The aim of the HSFS was to reduce feed allowance by increasing stocking rate and grazing HSFS pastures to a lower postgrazing surface sward height (PGSSH) than either the MPFS or HCFS. In all $3 \mathrm{yr}$, animals were turned out to grass during the day beginning in early February, and during day and night beginning in early March. Animals were on grass day and night until mid-November, when they were housed only at night. After December 1 , they were housed day and night. During the housed period, animals were fed grass silage ad libitum. The concentrate supplementation pattern for each system is shown in Table 3. Each FS was applied immediately postpartum to all multiparous animals.

\section{Grazing Management}

The experimental area was a permanent grassland site containing greater than $80 \%$ perennial ryegrass (Lolium perenne). Fifty-four paddocks were grouped into 18 sets of 3 (balanced by location and soil type) and randomly assigned to each FS. Each system consisted of 18 paddocks of on average 0.89 ha for MPFS and HCFS, and 0.81 ha for HSFS. Within each paddock, the 3 strains grazed separate areas that were defined using temporary electric fences. In the MPFS and HCFS, the subpaddocks for the HD and NZ strains were 0.29 ha, whereas for the HP strain, paddocks were 0.31 ha. In the HSFS, both the HD- and NZ-strain subpaddocks 
Table 3. Concentrate supplementation strategy $^{1}(\mathrm{~kg} / \mathrm{d}$ per cow $)$.

\begin{tabular}{lllll}
\hline Feeding system & $\begin{array}{l}\text { Calving to } \\
\text { March 15 }\end{array}$ & $\begin{array}{l}\text { March 15 to } \\
\text { March 31 }\end{array}$ & $\begin{array}{l}\text { April 1 to } \\
\text { early May }\end{array}$ & $\begin{array}{l}\text { Early May } \\
\text { to end of } \\
\text { lactation }\end{array}$ \\
\hline Moorepark & 6 & 4 & 2 & 0 \\
High stocking rate & 6 & 4 & 2 & 0 \\
High concentrate & 8 & 8 & 6 & 4 \\
\hline
\end{tabular}

${ }^{1}$ All primiparous animals were maintained on $7 \mathrm{~kg} / \mathrm{d}$ for a pre-experimental period of $4 \mathrm{wk}$.

were 0.26 ha, and the HP-strain subpaddocks were 0.28 ha. Previous measurements had established that these allocations were likely to achieve common PGSSH for each strain. Grazing management was similar to that outlined previously (Dillon et al., 1995). Grass silage was harvested from 0.45 and 0.35 of feeding system areas in late May (first silage harvest) and early July (second silage harvest), respectively. For the remainder of the season, all of the area within the feeding system was available for grazing. A rotational grazing management system was practiced. Residency time was determined by the achievement of predetermined pasture allowances ( $\mathrm{kg} / \mathrm{d}$ of DM per cow) within a target PGSSH ( 7 to $8 \mathrm{~cm}$ for the MPFS and HCFS; 6 to $7 \mathrm{~cm}$ for the HSFS). Target PGSSH were reached in residency times that ranged from 1.5 to $2.5 \mathrm{~d}$ per subpaddock over the experimental period. Grazing management was accomplished by weekly monitoring of farm grass cover (O'Donovan, 2000).

The subpaddock residency time of the cows in both the HSFS and MPFS was the same, i.e., similar grazing rotation; therefore, the cows in the HSFS were forced to graze to a lower PGSSH throughout the grazing season. The grazing rotation in the HCFS moved independently to that in the MPFS and HSFS, however the HCFS group grazed to a similar PGSSH as the animals on MPFS. Pasture quality was maintained in this system by removing surplus grass throughout the experiment as silage (O'Donovan, 2000).

\section{Animal Measurements}

During the $3 \mathrm{yr}$ of the study, individual milk yields were recorded on 5 consecutive days/week. The milk fat, protein, and lactose concentrations were determined using a Milkoscan 203 (Foss Electric DK-3400, Hillerød, Denmark) from successive morning and evening samples collected once weekly. The BW of each animal was recorded weekly. Each BW was recorded electronically, using portable weighing scales and Winweigh software package (Tru-Test Ltd., Auckland, New Zealand). The scales were calibrated weekly against known weights. The BCS was recorded every $3 \mathrm{wk}$ during the lactation on a 0 -to- 5 scale $(0=$ emaciated, $5=$ extremely fat $)$ with increments of 0.25 as outlined by Lowman et al. (1976). The first BW and BCS data were recorded at $24 \mathrm{~h}$ postpartum.

\section{Feed Measurements}

Pregrazing herbage yield (above $4 \mathrm{~cm}$ horizon) was determined on each grazing paddock based on 4 strips ( $0.80 \mathrm{~m}$ wide; 4.5 to $5.5 \mathrm{~m}$ long) of grass cut with an Agria mower (Agria-Werke GmbH, Mockmuhl/Wurtt, Germany). The grass from each strip was weighed and sampled and a subsample was dried overnight at $90^{\circ} \mathrm{C}$ for DM determination. The remaining herbage samples from each paddock were bulked and a further subsample taken $(\sim 100 \mathrm{~g})$ and freeze-dried and used for chemical analysis.

During each rotation, 30 pregrazing sward surface heights were recorded for each strain within each paddock immediately before grazing with a further 30 postgrazing sward surface heights taken immediately after grazing (Hutchings, 1991).

Chemical analysis. The composite herbage samples for each week were analyzed for modified acid detergent fiber (Clancy and Wilson, 1966), OM digestibility (Morgan et al., 1989), and Kjeldahl N. Similarly, in periods of silage supplementation, a composite grass silage sample for each week was analyzed for residual moisture, DM digestibility (Tilley and Terry, 1963), Kjeldahl N, modified ADF, and NDF (Van Soest et al., 1966). Concentrates were sampled weekly, bulked over each month, and analyzed for DM, total N, crude fiber, NDF, oil, and ash.

\section{Data Handling}

The data set was divided into 2 periods for the purpose of statistical analysis. Firstly, the production, BW, and BCS data were analyzed over the complete lactation (wk 3 of year to wk 53, inclusive) in all $3 \mathrm{yr}$. A second data set was created to examine the performance of each group exclusively during the period in lactation when the 3 feeding systems were in place (wk 10 of year to wk 45, inclusive) in all $3 \mathrm{yr}$. In early lactation (February and March) and late lactation (mid-Novem- 
ber/December), when cows were housed by night or by night and day, the various feed systems were not in place.

\section{Statistical Analysis}

Data were analyzed using a repeated measures model (PROC MIXED) described below using the statistical procedures of SAS (SAS Institute, 2002). Cow was included as a random effect, and year, parity, strain of $\mathrm{HF}$, and feed system were included as fixed effects. Each year, the newly introduced animals were selected within strain and parity on calving date and pre-experimental milk yield. Animals present from the previous year were maintained in the same feed system. To improve the accuracy of the model, pre-experimental milk yield, BW, and BCS were used as covariates specific to the traits being analyzed. The following model was used:

$$
\begin{aligned}
& \mathrm{Y}_{i j k l}=\mu+\operatorname{cov} \mathrm{e}+\mathrm{R}_{i}+\mathrm{L}_{j}+\mathrm{S}_{k}+\mathrm{F}_{l} \\
& +\mathrm{LS}_{j k}+\mathrm{SF}_{k l}+\mathrm{LF}_{j l}+\mathrm{LSF}_{j k l}+\mathrm{e}_{i j k l},
\end{aligned}
$$

where $\mathrm{Y}_{i j k l}=$ the performance of the animal in yr $i$ of parity $j$ and strain $k$ on feed $l, \mathrm{R}_{i}=$ the effect of $i$ th $\mathrm{yr}$ ( $\mathrm{i}=1,2,3), \mathrm{L}_{j}=$ parity $(\mathrm{j}=1,2,3), \mathrm{S}_{k}=$ strain of $\mathrm{HF}$ ( $k=\mathrm{HP}, \mathrm{HD}$, or NZ); $\mathrm{F}_{l}=$ the effect of the $l$ th feed system ( $l=$ MPFS, HSFS, HCFS), and $\mathrm{e}_{i j k l}=$ the residual error term.

For the milk production variables, the covariates used were pre-experimental milk production, individual animal predicted difference for milk production, and calving date for each animal on the study. Models for BW and BCS included covariates for pre-experimental BW and condition score, gestation length, and calving date. Owing to the differences between strains in terms of the pre-experimental values, these covariates were centered within strain before inclusion. That is, the deviations from the strain mean were used as the covariates. The incorporation of individual animal covariates within the model reduced the residual error term, therefore explaining more of the variation within strains.

Orthogonal contrasts (Snedecor and Cochran, 1980) were used to make a number of comparisons. The PRODL contrast refers to the comparison of animals selected purely for high milk production potential (HP strain) with animals that are not selected aggressively for milk production (HD and NZ strains)[PRODL; HP vs. $(\mathrm{HD}+\mathrm{NZ}) / 2$ ]. The LOWP contrast refers to the comparison of exclusively lower production groups, therefore comparing the lower production North American HF (HD strain) to the NZ strain (LOWP; HD vs. NZ). The effect of FS was determined by making the following comparisons with the MPFS (control): MPFS vs.
HSFS and MPFS vs. HCFS. The effect of strain of HF on response to stocking rate and concentrate supplementation was also tested using the Student's t-test to compare the differential in performance of each strain in the MPFS with the performance in the HSFS and HCFS during the feed system period.

\section{RESULTS}

Table 4 shows the results of the chemical analyses of the herbage, grass silage, and concentrate offered in each of the 3 yr. Data in Table 5 shows the concentrate input, pre- and postgrazing sward heights, pregrazing yield, and daily herbage allowance for each of the treatment groups for both the complete 3 -yr data set and for the specific periods when the feeding systems were in place. These results show that although the 3 feed systems had similar pregrazing heights, concentrate supplementation, postgrazing sward height and daily herbage allowance did differ significantly between feed systems.

\section{Milk Production}

Complete lactation analysis. There was a significant interaction between strain of HF and FS for all milk yield variables (Table 6). There are also individual effects of strain of HF and FS evident in the data. The HP strain had the highest $(P<0.001)$ total lactation milk yield $(6958 \mathrm{~kg})$, the NZ strain the lowest $(6141$ $\mathrm{kg}$ ) milk yield, and the HD strain was intermediate $(6584 \mathrm{~kg})$. The HP strain had the highest $(P<0.001)$ SCM yield (Tyrell and Reid, 1965) (6629 kg), whereas no difference was observed between the HD $(6359 \mathrm{~kg})$ and NZ strains ( $6278 \mathrm{~kg}$ ). The HP strain had the highest peak milk yield $(34.8 \mathrm{~kg})$, total protein $(241 \mathrm{~kg})$, and total lactose yields $(326 \mathrm{~kg})$, with the NZ strain the lowest (30.2, 224, $288 \mathrm{~kg}$, respectively), and the HD strain was intermediate $(32.8,235,308 \mathrm{~kg}$, respectively). The HP strain also produced more $(P<0.001)$ fat over the lactation $(279 \mathrm{~kg})$ with no significant difference between the HD (268 kg) and NZ strains (275 kg).

Similarly, FS had a significant effect on all milk production parameters. The cows in HCFS produced the highest $(P<0.001)$ yield of milk $(7199 \mathrm{~kg}), \mathrm{SCM}(7040$ $\mathrm{kg})$, peak milk (34.4 kg), protein $(259 \mathrm{~kg})$, and lactose (341 kg), with HSFS the lowest (6133, 6025, 31.2, 216, and $285 \mathrm{~kg}$, respectively), with the MPFS being intermediate $(6352,6200,32.1,225$ and $296 \mathrm{~kg}$, respectively). The cows in the HCFS also produced the highest $(P<0.001)$ yield of fat over lactation $(296 \mathrm{~kg})$ with no significant difference between the MPFS and HSFS (265 and $260 \mathrm{~kg}$, respectively). Significant interactions 


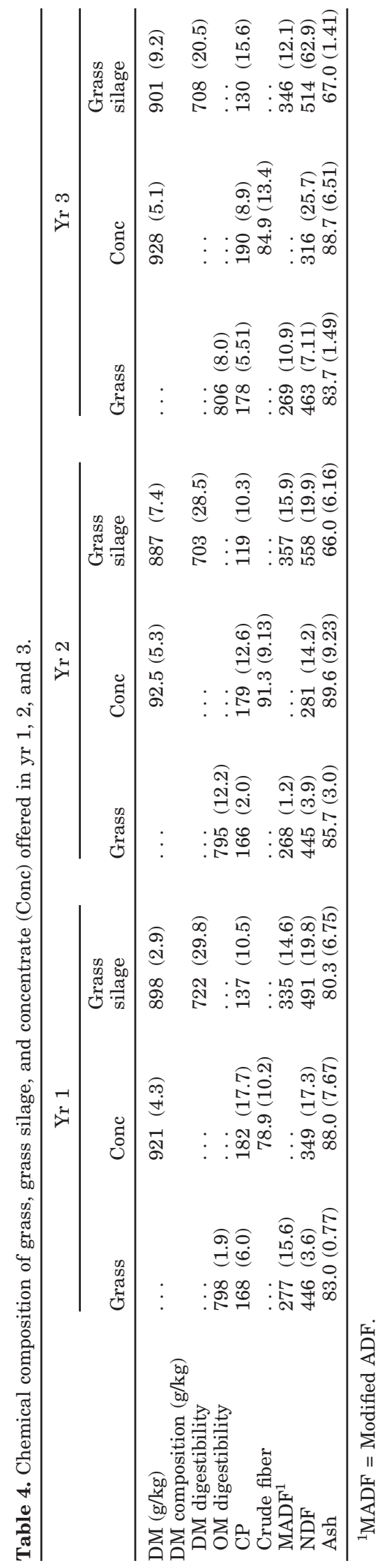

between strain of $\mathrm{HF}$ and FS were observed for all milk yield variables.

Parity had a significant effect on total lactational milk production (significance levels are included in Table 6$)$. Third-parity cows had the highest $(P<0.001)$ yield of milk (7436 kg), SCM (7449 kg), peak daily milk $(37.1 \mathrm{~kg})$, fat $(307 \mathrm{~kg})$, protein $(259 \mathrm{~kg})$, and lactose (340 $\mathrm{kg})$, the first-parity cows had the lowest $(P<0.001)$ (5533, 5322, 26.8, 233, 199, and $266 \mathrm{~kg}$, respectively), and the second-parity cows were intermediate for all variables $(6850,6698,33.7,281,242$, and $317 \mathrm{~kg}$, respectively). First-parity animals also had lower $(P<$ $0.01)$ protein concentration $(35.2 \mathrm{~g} / \mathrm{kg})$ compared with animals of second and third parity (35.9 and $36.0 \mathrm{~g} /$ $\mathrm{kg}$, respectively).

Feed system period analysis. During the feed system period, the interaction of strain of HF and FS as well as effects of strain of HF and FS were observed (Table 7). Feed system had a significant effect on all variables measured. The cows in the HCFS produced the highest $(P<0.001)$ daily yield of milk $(23.4 \mathrm{~kg} / \mathrm{d})$, SCM $(22.6 \mathrm{~kg} / \mathrm{d})$, fat $(933 \mathrm{~g} / \mathrm{d})$, protein $(851 \mathrm{~g} / \mathrm{d})$, and lactose $(1111 \mathrm{~g} / \mathrm{d})$, the cows in the HSFS the lowest ( $P$ $<0.05)(19.5 \mathrm{~kg}, 18.9 \mathrm{~kg}, 806 \mathrm{~g}, 694 \mathrm{~g}$, and $908 \mathrm{~g}$, per $\mathrm{d}$, respectively), and that of the cows in MPFS was intermediate $(20.2 \mathrm{~kg}, 19.7 \mathrm{~kg}, 831 \mathrm{~g}, 726 \mathrm{~g}$, and $939 \mathrm{~g}$, per day, respectively). The HCFS group had lower ( $P$ $<0.01)$ fat composition $(40.5 \mathrm{~g} / \mathrm{kg})$ compared with the HSFS group (41.6 g/kg), with MPFS intermediate (41.1 $\mathrm{g} / \mathrm{kg}$ ). The cows in the HCFS produced the highest protein and lactose content (36.8 and $47.5 \mathrm{~g} / \mathrm{kg}$, respectively), with no significant difference between the MPFS ( 36.1 and $46.4 \mathrm{~g} / \mathrm{kg}$, respectively) and HSFS (36.0 and $46.7 \mathrm{~g} / \mathrm{kg}$, respectively).

Significant strain $\times$ FS interactions were observed for daily yield of milk, SCM, fat, protein, lactose, and protein composition. The interaction of strain of $\mathrm{HF}$ and FS for daily milk production is shown in Figure 1. The reduction in daily milk production in the HSFS was similar for both the HD and NZ strains (reducing daily milk yield by 0.5 and $0.6 \mathrm{~kg} / \mathrm{d}$, respectively, relative to the MPFS). In comparison, greater $(P<0.05)$ sensitivity to the HSFS was observed among the HP strain over this period, with average daily milk production being reduced by $1.2 \mathrm{~kg} / \mathrm{d}$. A greater $(P<0.05)$ reduction in daily SCM, fat, and lactose yield was observed among the HP strain (with reductions in daily production of $1.3 \mathrm{~kg}, 70 \mathrm{~g}$, and $58 \mathrm{~g}$, respectively) compared with the HD $(0.3 \mathrm{~kg}, 24 \mathrm{~g}$, and $32 \mathrm{~g})$ and NZ strains $(0.7 \mathrm{~kg}, 16 \mathrm{~g}$, and $37 \mathrm{~g}$, respectively). The HSFS had a similar affect on all strains in terms of protein yield and milk composition.

The milk production of the NZ strain is less sensitive to concentrate input compared with the HP and HD 
Table 5. Differences between feed systems ${ }^{1}$ (MP, HS, HC) in concentrate input and pasture management in 3 strains of Holstein-Friesian ${ }^{2}$ (HP, HD, NZ).

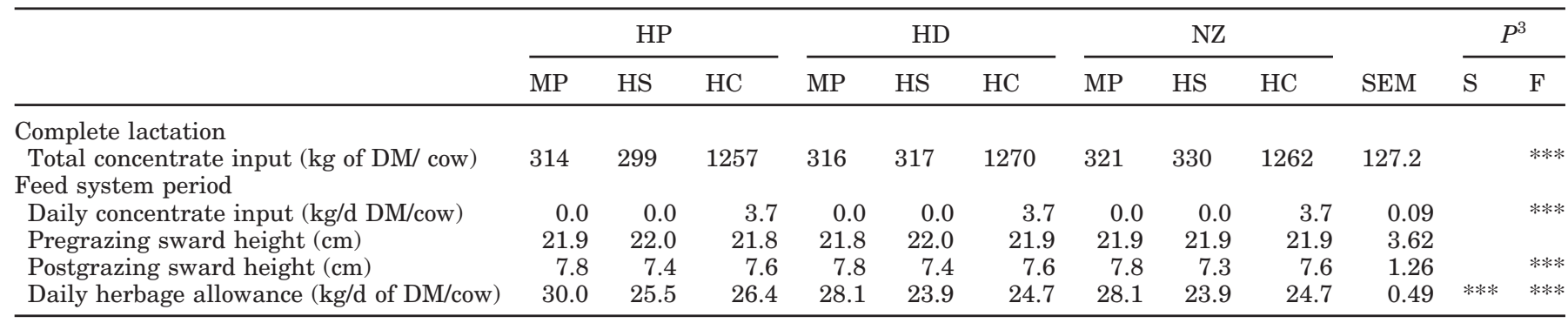

${ }^{1}$ Feed systems: MP = high grass feed system; HS = high stocking rate feed system; HC = high concentrate feed system.

${ }^{2}$ Strains: HP = high production; HD = high durability; NZ = New Zealand.

${ }^{3}$ Effects: $\mathrm{S}=$ effect of strain of Holstein-Friesian; F = effect of feed system. There was no significant strain of $\mathrm{HF} \times$ feed system interaction detected.

$* * * P<0.001$.

groups. Table 8 shows the effect of strain of HF on milk production response to increased concentrate (MPFS vs. HCFS) during the feed system period. The milk production response to increased concentrate supplementation was significantly greater for the HP and HD strains $(1.08$ and $1.00 \mathrm{~kg}$ of milk/kg of concentrate, respectively) than the NZ strain $(0.43 \mathrm{~kg}$ of milk/kg of concentrate). Similar trends were observed in terms of daily SCM, protein, and lactose yields. The HD strain displayed a greater response in fat yield compared with the HP and NZ strains.

\section{BW and BCS}

Complete lactation analysis. The effects of strain of $\mathrm{HF}$ and FS on BW and BCS over the entire lactation are displayed in Table 9 . Immediately postpartum, both the HP and HD strains (553 and $556 \mathrm{~kg}$, respectively) were heavier $(P<0.001)$ than the NZ strain $(517 \mathrm{~kg})$. The HD strain was heaviest $(P<0.05)$ at nadir BW, and at drying-off (500 and $596 \mathrm{~kg}$, respectively), the NZ strain the lightest (463 and $553 \mathrm{~kg}$, respectively), and the HP strain was intermediate $(491$ and $570 \mathrm{~kg}$, respectively). The NZ strain had the highest $(P<0.001)$ BCS immediately postpartum (3.37), at nadir BCS (2.84), and at drying-off (3.13), the HP strain the lowest $(P<$ $0.01)(3.17,2.45$, and 2.68 , respectively), and the HD strain was intermediate $(3.24,2.65$, and 2.93 , respectively). Strain of HF had no significant effect on BW change from calving to nadir BW, however the HP strain lost significantly more body condition $(-0.73)$ from calving to nadir, compared with the HD (-0.59) and NZ strains $(-0.55)$. The HD strain had a greater $(P<0.001) \mathrm{BW}$ gain from nadir BW to the end of lactation $(95.7 \mathrm{~kg})$, compared with the HP $(82.8 \mathrm{~kg})$ and NZ strains $(86.1 \mathrm{~kg})$, with no difference in condition score gain between strains.
Feed system had a significant effect on BW and BCS. The cows in the HCFS were heaviest $(P<0.05)$ at nadir BW (491 kg) and at drying-off (586 kg), whereas no difference was observed between the MPFS and HSFS at nadir BW (482 and 481, respectively) or at dryingoff (567 and 566, respectively). The HCFS had the highest $(P<0.001)$ nadir BCS $(2.77)$ and BCS at drying-off (3.03), with the MPFS and HSFS groups having the same BCS at nadir (2.59) and at drying-off (2.84 and 2.87, respectively). Cows in the HCFS gained more BW between nadir BW and drying-off $(96.0 \mathrm{~kg}$ ) compared with the HSFS and MPFS (84.0 and $83.3 \mathrm{~kg}$, respectively). Similarly, the cows in the HCFS lost significantly less $(P<0.05)$ BCS from calving to nadir $(0.51)$, compared with HSFS and MPFS (0.64 and 0.72, respectively).

Animals of third parity were heaviest $(P<0.001)$ immediately postpartum, at nadir BW, and at dryingoff (580, 522, and $605 \mathrm{~kg}$, respectively), first-lactation animals the lightest $(501,438$, and $531 \mathrm{~kg}$, respectively), and second-lactation animals were intermediate (545, 495, and $573 \mathrm{~kg}$, respectively). Primiparous animals had the highest BCS immediately postpartum (3.26), and at drying-off (2.93), whereas the secondparity animals had the lowest BCS immediately postpartum (3.18), and the third-parity animals had the lowest BCS at drying-off (2.87). Second-parity animals had lower $(P<0.05)$ BW and BCS loss between calving and nadir (50.6 $\mathrm{kg}$ and 0.56 , respectively) compared with the primiparous ( $63.5 \mathrm{~kg}$ and 0.63 , respectively) and third-parity animals $(57.8 \mathrm{~kg}$ and 0.69 , respectively).

Feed system period analysis. Strain of $\mathrm{HF}, \mathrm{FS}$, and parity had significant effects on BW and BCS during the feed system period (Table 10). The cows in the HCFS were heaviest at the beginning and end of the feed system period (524 and $583 \mathrm{~kg}$, respectively), and had 
Table 6. Effect of strain of Holstein-Friesian ${ }^{1}$ (HP, HD, NZ), feed system ${ }^{2}$ (MP, HS, HC), and interaction between strain of HF and FS on milk production over the complete lactation.

\begin{tabular}{|c|c|c|c|c|c|c|c|c|c|c|c|c|c|c|c|c|}
\hline & \multicolumn{3}{|c|}{ HP } & \multicolumn{3}{|c|}{ HD } & \multicolumn{3}{|c|}{$\mathrm{NZ}$} & \multirow[b]{2}{*}{ SEM } & \multicolumn{6}{|c|}{ Significance $^{3}$} \\
\hline & MP & HS & $\mathrm{HC}$ & MP & HS & $\mathrm{HC}$ & MP & HS & $\mathrm{HC}$ & & $\mathrm{S}$ & $\mathrm{F}$ & $\mathrm{L}$ & $\mathrm{S} \times \mathrm{F}$ & PRODL & LOWP \\
\hline Total milk yield (kg/cow) & 6799 & 6283 & 7877 & 6408 & 6176 & 7360 & 6039 & 5940 & 6444 & 124.8 & $* * *$ & $* * *$ & $* * *$ & $* * *$ & $* * *$ & $* * *$ \\
\hline $\mathrm{SCM}^{4}$ yield (kg/cow) & 6489 & 5999 & 7376 & 5976 & 6012 & 7074 & 6120 & 6065 & 6648 & 104.5 & $* * *$ & $* * *$ & $* * *$ & $* * *$ & $* * *$ & \\
\hline Maximum yield (kg/d per cow) & 34.5 & 32.7 & 37.2 & 32.1 & 31.1 & 35.2 & 29.8 & 29.8 & 31.0 & 0.53 & $* * *$ & $* * *$ & $* * *$ & $*$ & $* * *$ & $* * *$ \\
\hline Fat yield (kg/cow) & 277 & 256 & 304 & 252 & 257 & 295 & 267 & 269 & 288 & 5.1 & * & $* * *$ & $* * *$ & $* *$ & $* * *$ & \\
\hline Protein yield (kg/cow) & 234 & 217 & 272 & 221 & 219 & 264 & 219 & 213 & 240 & 3.6 & $* * *$ & $* * *$ & $* * *$ & $* * *$ & $* * *$ & $* * *$ \\
\hline Lactose yield (kg/cow) & 315 & 291 & 371 & 289 & 288 & 346 & 282 & 277 & 305 & 6.0 & $* * *$ & $* * *$ & $* * *$ & $* * *$ & $* * *$ & $* * *$ \\
\hline \multicolumn{17}{|l|}{ Milk composition (\%) } \\
\hline Fat & 40.6 & 41.0 & 40.0 & 40.9 & 41.1 & 40.1 & 43.9 & 45.6 & 44.5 & 0.07 & $* * *$ & * & $\dagger$ & & $* * *$ & $* * *$ \\
\hline Protein & 34.5 & 34.8 & 35.4 & 35.6 & 35.5 & 35.8 & 36.5 & 36.1 & 37.2 & 0.04 & $* * *$ & $*$ & $* *$ & & $* * *$ & $* *$ \\
\hline Lactose & 46.3 & 46.6 & 47.7 & 46.6 & 46.7 & 47.1 & 46.7 & 46.6 & 47.5 & 0.02 & & **** & & & & \\
\hline
\end{tabular}

${ }^{1}$ Strains: HP = high production; HD = high durability; NZ = New Zealand.

${ }^{2}$ Feed systems: MP = high grass feed system; HS = high stocking rate feed system; HC = high concentrate feed system.

${ }^{3}$ Effects: $\mathrm{S}=$ effect of strain of Holstein-Friesian; $\mathrm{F}=$ effect of feed system; $\mathrm{L}=$ effect of parity; $\mathrm{S} \times \mathrm{F}=$ effect of interaction between strain of Holstein-Friesian and feed system; PRODL = linear contrast of the HP group with low production groups [HP vs. $(\mathrm{HD}+\mathrm{NZ}) / 2]$; LOWP = linear contrast of HD and NZ strains (HD vs. NZ).

${ }^{4} \mathrm{SCM}=$ Solids-corrected milk.

$* * * P<0.001, * * P<0.01, * P<0.05, \dagger P<0.10$

Table 7. Effect of strain of Holstein-Friesian ${ }^{1}$ (HP, HD, NZ), feed system ${ }^{2}$ (MP, HS, HC), and parity on milk production during the feed system period.

\begin{tabular}{|c|c|c|c|c|c|c|c|c|c|c|c|c|c|c|c|c|}
\hline & \multicolumn{3}{|c|}{$\mathrm{HP}$} & \multicolumn{3}{|c|}{ HD } & \multicolumn{3}{|c|}{$\mathrm{NZ}$} & \multirow[b]{2}{*}{ SEM } & \multicolumn{6}{|c|}{ Significance $^{3}$} \\
\hline & MP & HS & $\mathrm{HC}$ & MP & HS & $\mathrm{HC}$ & MP & HS & $\mathrm{HC}$ & & $\mathrm{S}$ & $\mathrm{F}$ & $\mathrm{L}$ & $\mathrm{S} \times \mathrm{F}$ & PRODL & LOWP \\
\hline \multicolumn{17}{|l|}{ Yield } \\
\hline Milk (kg/d per cow) & 22.0 & 20.8 & 26.0 & 20.1 & 19.6 & 23.3 & 18.7 & 18.1 & 20.3 & 0.45 & $* * *$ & $* * *$ & $* * *$ & $* *$ & $* * *$ & $* * *$ \\
\hline $\mathrm{SCM}^{4}(\mathrm{~kg} / \mathrm{d}$ per cow $)$ & 20.9 & 19.6 & 24.3 & 19.2 & 18.9 & 22.1 & 19.0 & 18.3 & 20.9 & 0.32 & $* * *$ & $* * *$ & $* * *$ & $* *$ & $* * *$ & $*$ \\
\hline Fat (g/d per cow) & 887 & 817 & 980 & 821 & 797 & 928 & 818 & 802 & 891 & 16.7 & $* * *$ & $* * *$ & $* * *$ & $*$ & $* * *$ & \\
\hline Protein (g/d per cow) & 774 & 722 & 911 & 742 & 700 & 864 & 697 & 659 & 778 & 12.9 & $* * *$ & $* * *$ & $* * *$ & $* *$ & $* * *$ & $* * *$ \\
\hline Lactose (g/d per cow) & 1032 & 974 & 1245 & 943 & 911 & 1119 & 874 & 837 & 970 & 22.1 & $* * *$ & $* * *$ & $* * *$ & $* *$ & $* * *$ & $* * *$ \\
\hline \multicolumn{17}{|l|}{ Milk composition (\%) } \\
\hline Fat & 39.4 & 39.6 & 38.6 & 40.3 & 40.5 & 39.3 & 43.6 & 44.9 & 43.5 & 0.08 & $* * *$ & $\dagger$ & & & **** & $* * *$ \\
\hline Protein & 34.6 & 35.2 & 35.6 & 36.3 & 36.0 & 36.4 & 37.4 & 36.8 & 38.4 & 0.04 & $* * *$ & * & & $*$ & $* * *$ & $* * *$ \\
\hline Lactose & 46.3 & 46.9 & 47.6 & 46.4 & 46.7 & 47.2 & 46.5 & 46.4 & 47.7 & 0.03 & & $* * *$ & & & & \\
\hline
\end{tabular}

${ }^{1}$ Strains: HP = high production; HD = high durability; NZ = New Zealand.

${ }^{2}$ Feed systems: MP = high grass feed system; HS = high stocking rate feed system; HC = high concentrate feed system.

${ }^{3}$ Effects: $\mathrm{S}=$ effect of strain of Holstein-Friesian; F = effect of feed system; L = effect of parity; $\mathrm{S} \times \mathrm{F}=$ effect of interaction between strain of Holstein-Friesian and feed system; PRODL = linear contrast of the HP group with low production groups [HP vs. (HD + NZ)/2]; LOWP = linear contrast of HD and NZ strains (HD vs. NZ).

${ }^{4} \mathrm{SCM}=$ Solids-corrected milk.

$* * * P<0.001, * * P<0.01, * P<0.05, \dagger P<0.10$ 
Table 8. Effect of strain of Holstein-Friesian ${ }^{1}$ on milk production response to concentrate supplementation during the feed system period.

\begin{tabular}{|c|c|c|c|c|}
\hline & $\mathrm{HP}$ & HD & NZ & $P$ \\
\hline Daily milk yield response (kg/kg) & $1.08^{\mathrm{a}}$ & $1.00^{\mathrm{a}}$ & $0.43^{\mathrm{b}}$ & \\
\hline Daily $\mathrm{SCM}^{2}$ yield response $(\mathrm{kg} / \mathrm{kg})$ & $0.92^{\mathrm{a}}$ & $0.86^{\mathrm{a}}$ & $0.51^{\mathrm{b}}$ & \\
\hline Daily fat yield response $(\mathrm{g} / \mathrm{kg})$ & $25^{\mathrm{a}}$ & $38^{\mathrm{b}}$ & $20^{\mathrm{a}}$ & \\
\hline Daily protein yield response $(\mathrm{g} / \mathrm{kg})$ & $37^{\mathrm{a}}$ & $42^{\mathrm{a}}$ & $22^{\mathrm{b}}$ & \\
\hline Daily lactose yield response (g/kg) & $58^{\mathrm{a}}$ & $56^{\mathrm{a}}$ & $26^{\mathrm{b}}$ & ** \\
\hline
\end{tabular}

${ }^{a, b}$ Means with different superscripts within the same row are significantly different.

${ }^{1} \mathrm{HP}=$ High production; HD = high durability; NZ = New Zealand.

${ }^{2} \mathrm{SCM}=$ Solids-corrected milk.

$* * P<0.01, * P<0.05$.

the highest BW gain over the 27 -wk FS period $(60 \mathrm{~kg})$. The HSFS were lighter $(P<0.10)$ than the MPFS at wk 1 (508 and $514 \mathrm{~kg}$, respectively), and at wk 26 (563 and $566 \mathrm{~kg}$, respectively). The BW change did not differ between the HSFS and MPFS over the period (54.5 and $52.0 \mathrm{~kg}$, respectively). The cows in the HCFS had higher BCS at the start and end of the FS period (2.90 and 3.03 , respectively), compared with HSFS (2.82 and 2.87, respectively) and MPFS (2.82 and 2.83, respectively). The HCFS had the highest $(P<0.001)$ BCS gain over the period (0.15), with no difference between the MPFS $(-0.02)$ and HSFS (0.04) systems.

The interaction of strain of HF and FS approached significance $(P=0.14)$ for BW change from wk 1 to 26 postpartum due to the higher BW gain exhibited by the $\mathrm{HD}$ and NZ strains relative to the HP group in both the MPFS and HCFS.

\section{DISCUSSION}

A farmlet study allows greater feeding and management control than a large population study, where it is difficult to account for the influences of on-farm decisions. The limitations of the former analysis arise from the lack of replication relative to population studies. Such limitations are overcome by repeating the experiment over a number of years. This data set provides a unique opportunity to investigate the performance of divergent strains of $\mathrm{HF}$ dairy cow in 3 pasture-based systems of milk production. By analyzing the data set exclusively during the feed system period, the biological significance of any interaction between strain of $\mathrm{HF}$ and FS can be quantified accurately.

A genotype $x$ environment interaction occurs when animals differ in their ability to perform in different environments (Falconer, 1990). A number of studies have shown a genotype $\times$ environment interaction in dairy production systems (Veerkamp et al., 1994; Boettcher et al., 2003). The existence of a genotype $x$

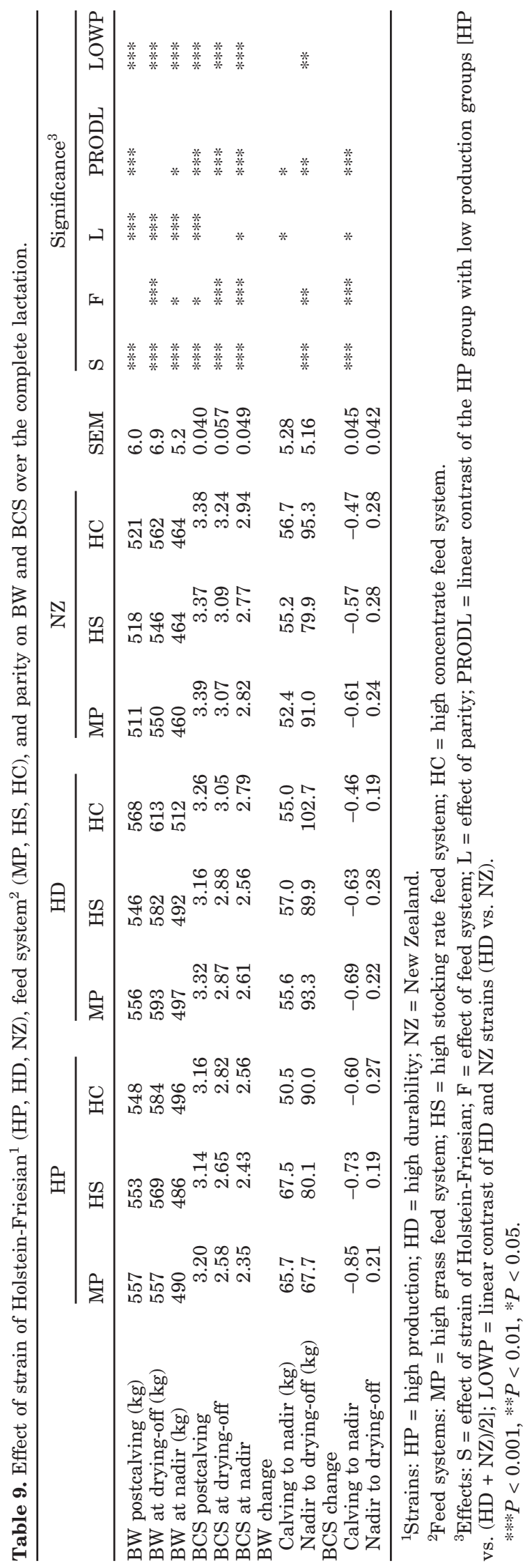

Journal of Dairy Science Vol. 88, No. 3, 2005 


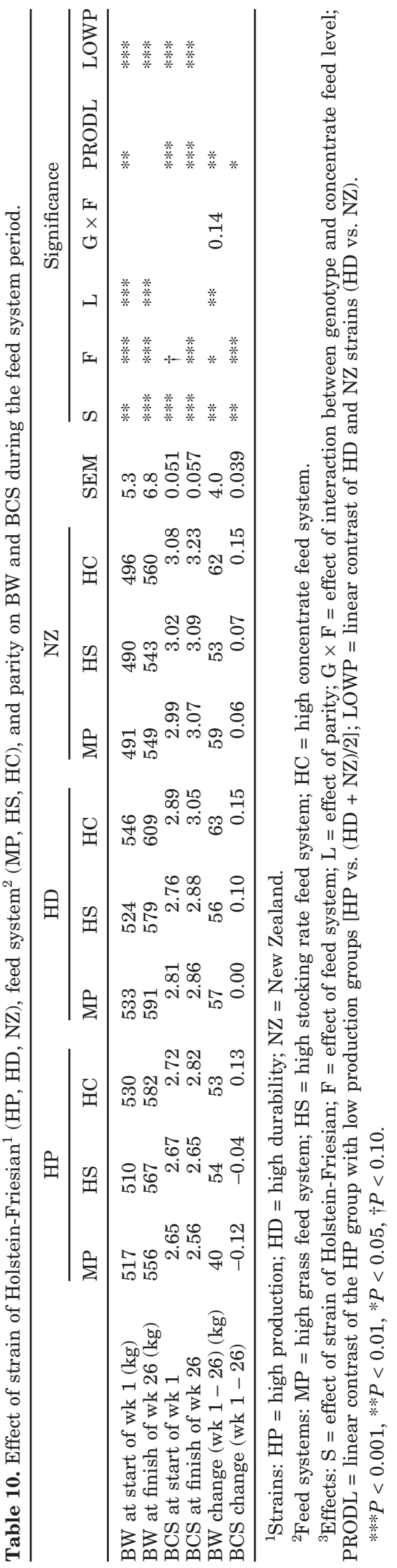

environment interaction can be in the form of a "scaling effect," where the difference in the level of performance between 2 genotypes is smaller at a low level than a high feeding level, or a "re-ranking" where 2 genotypes rank differently in contrasting feeding systems. It is only possible to investigate the "scaling effect" with the present data set.

Kennedy et al. (2003) showed that with a high proportion of forage in the diet, high genetic merit dairy cows are not capable of eating much more than low genetic merit dairy cows, whereas on high concentrate diets, high genetic merit cows have the advantage of higher DM intakes. Hence, the differences in milk yield between genotypes are smaller in a high grass diet because intake is limited by constraining factors in the diet such as physical bulk, or by the relatively slow rate of intake that can be achieved by grazing cows compared with a system that entails a high level of concentrate supplementation.

\section{Effect of Strain}

The overall level of milk production achieved in the present study is similar to that obtained in previous studies at this center (Kennedy et al., 2002). Kennedy et al. (2002) showed total lactation milk yields of 6421 and $7389 \mathrm{~kg}$ with medium and high genetic merit $\mathrm{HF}$ cows, respectively, on low concentrate, and 7196 and $8461 \mathrm{~kg}$, respectively, on a high concentrate system. These levels of production are much higher than that achieved in other pasture-based systems with high genetic merit cows. Kolver (2001) obtained $4678 \mathrm{~kg}$ of milk per cow with high genetic merit North American HF cows in a New Zealand grazing system with a low stocking rate. The milk protein composition achieved in the present experiment may be considered high for cows on a high forage system. Similar milk composition has been reported previously at this center (Buckley et al., 2000; Kennedy et al., 2002) when animals have been given access to high quality perennial ryegrass swards over a long grazing season.

The difference in observed milk production between the HP strain and the 2 low production strains (HD and $\mathrm{NZ}$ ) is in agreement with the differences in predicted difference for milk, and similar to that observed in previous studies (Buckley et al., 2000; Boettcher et al., 2003). This higher milk production has been achieved successfully because milk production is a highly heritable selection criterion (Evans et al., 2002). The lower overall milk production and higher composition of the NZ strain compared with North American strain has also been observed previously (Kolver et al., 2000). Kolver (2001) showed that in New Zealand, North American-derived Holstein-Friesian cows were heav- 


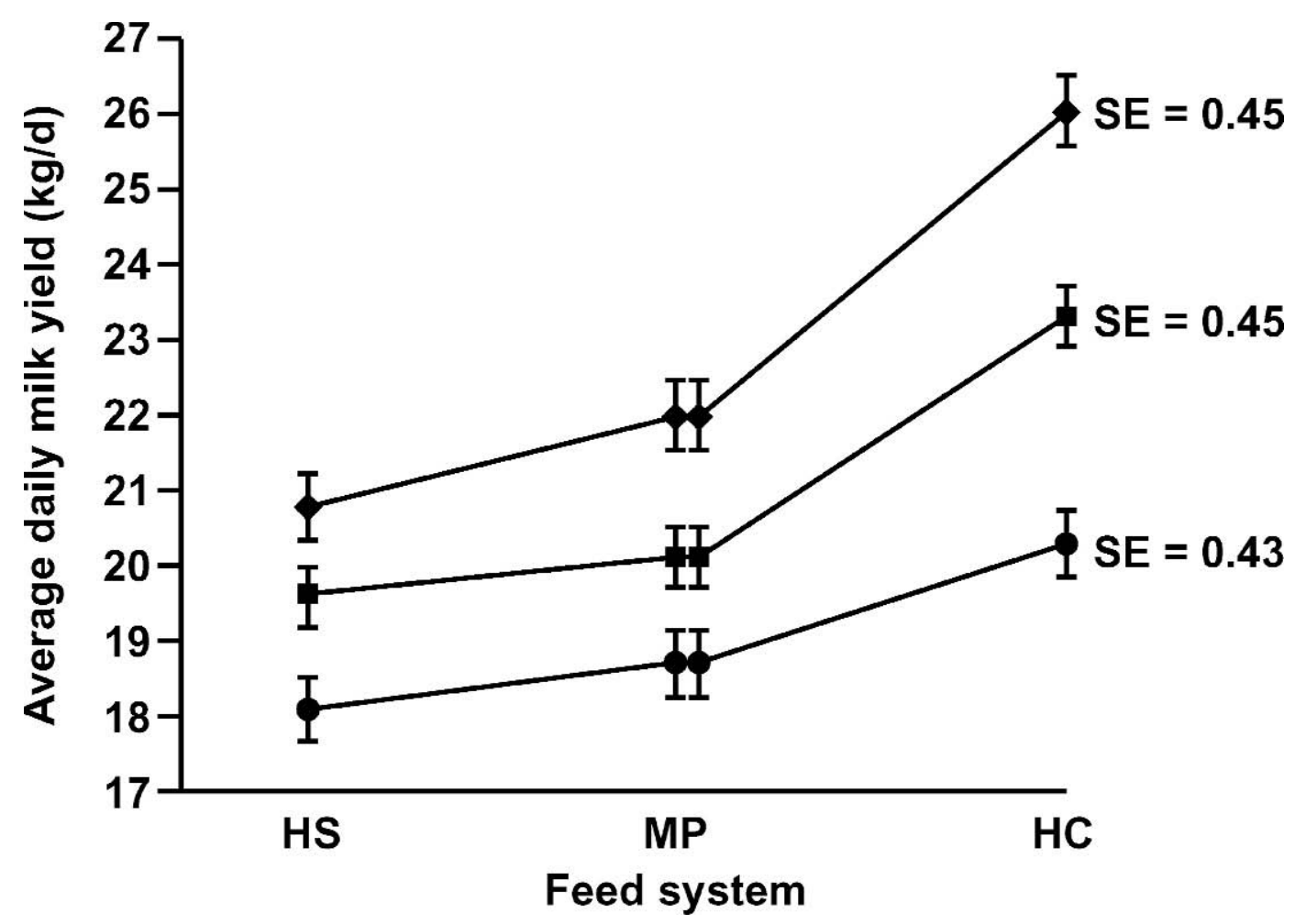

Figure 1. Effect of interaction between strain of Holstein-Friesian cow and feed system $(\mathrm{HS}=$ high stocking rate; MP = high grass; HC = high concentrate) on average daily milk production during the feed system period for the high production ( $\bullet)$, high durability ( $\mathbf{\square})$, and New Zealand (๑) Holstein-Friesian strains.

ier, produced more milk volume and protein yield, and had lower concentration of fat and protein than New Zealand-derived Holstein-Friesian cows.

Until recently, the breeding schemes of the North American HF cow population within Europe have been based solely on increased milk production. Such breeding programs increase the gap between energy intake and output in early lactation. For this reason a greater mobilization of BW and BCS is expected among the HP strain. The higher BW of the HD strain relative to the $\mathrm{HP}$ animals is understandable given their lower level of milk production, coupled with their higher muscularity.

The reduced BCS displayed by the HP cows is also expected because many studies have shown lower BCS in animals selected for higher milk yield (Berry et al., 2003) and because the correlated response in feed intake in early lactation, due to selection for milk yield, can cover only 40 to $48 \%$ of the extra requirement (Veerkamp et al., 1994). Selection on milk yield alone is expected to increase the mobilization of body reserves in early lactation, the magnitude and duration of which is related to reduced health and fertility (Buckley et al., 2003). Many studies have shown that cows genetically superior for milk production tend to have genetically lower BCS throughout lactation and greater BCS change in early lactation than those of lower genetic merit (Buckley et al., 2000). Dechow et al. (2002) suggests that as cows are selected for higher milk production and become genetically thinner, the amount of body condition lost postpartum is likely to increase at any given level of BCS at parturition.

The lower BW and higher BCS of the NZ strain is a consequence of the negative weighting on milk volume and BW within the New Zealand Breeding Worth index (Harris, 1998). Previous studies in New Zealand showed that offspring of North American HF sires were heavier and taller than the New Zealand HF. Kolver et al. (2000) showed that North American HF heifers had a higher BW and they were unable to maintain acceptable body condition and BW on a pasture-based diet when compared with the New Zealand Holstein $\mathrm{HF}$.

\section{Effect of FS}

The higher total lactation milk, SCM, fat, protein, and lactose yield achieved with the HCFS group is expected, given the large increase in energy supply with this FS. This is consistent with previous studies, which showed that total DMI increased with increasing pro- 
portion of concentrate in the diet (Bargo et al., 2002). The decline in milk fat content observed with HCFS was in agreement with previous findings (Bargo et al., 2002), and can be largely attributed to the reduced fiber content in the diet. The general increase in milk protein content on HCFS is likely attributable to increased energy intake and has been reported previously (Dillon and Crosse, 1997; Bargo et al., 2002).

The significant genotype $\times$ environment interaction observed for milk production over the complete lactation and during the feed system period agrees with similar farmlet studies (Kennedy et al., 2002), as well as large database studies (Boettcher et al., 2003). These interactions are explained by the large difference in response to additional energy intake between strains. The higher milk production response by the HP animals to a greater grass allowance in the MPFS demonstrates their greater nutritional stress, relative to the lower production strains. Differences in the response to additional energy input have been attributed to such factors as physiological stage, body condition, and milk production potential. As an animal approaches its maximum milk production potential, an increasing proportion of the energy supplied is retained as body lipid (Broster et al., 1985).

In the present study, the low response to concentrate supplementation from the NZ strain coupled with their higher BCS suggests that these animals achieved a greater proportion of their potential milk production in the MPFS than the HP strain. Coulon and Remond (1991) found that when energy requirements are not being met, concentrate supplementation appreciably influences the energy balance of the animal resulting in increased animal performance. Although body reserves usually buffer shortfalls in energy supply, prolonged mobilization is not possible due to innate metabolic adaptations within the animal (homeostasis). Consequently, high yielding cows are of lower body condition and display a more pronounced response to concentrate supplementation, as their energy demands for milk production are not fully met on a predominantly pasturebased diet. Many other studies using high genetic merit dairy cows for milk production have shown large responses to concentrate on pasture-based systems (Delaby et al., 2001; Kennedy et al., 2002).

The interaction of strain of HF and FS approached significance for BW change. This is mainly due to the lower BW gain of the HP animals in both the MPFS and HCFS. The lower BW gain among the HP strain over the feed system period may have arisen as a consequence of the higher milk production relative to the HD group during the feed system period. The energy intake resulting from increased grass allowance (in the MPFS) and additional concentrate supplementation (in the
HCFS) resulted in a larger milk production response in these systems rather than in BW gain. The lack of agreement between BW and BCS change has been observed previously (Sutter and Beever, 2000). These authors concluded that BW change was an inadequate index of body tissue mobilization in early lactation as it might be biased by increased gut content or water repletion of body tissue.

Historically, genetic selection in dairy cattle has been within country. However, global selection can increase the rate of genetic progress in dairy cattle by up to $17 \%$ compared with within-country selection (Lohuis and Dekkers, 1998). However, such success has in turn raised new doubts relating to the problem of genotype $x$ environment interaction, as exemplified in this study. In a seasonal pasture-based system, characteristics other than milk production, such as reproductive performance and animal health, are important (Veerkamp et al., 2002). Ultimately, the optimum cow for pasturebased systems can only be identified by combining all traits (production and health) of economic significance in a weighted index of economic merit and choosing sires at the top of this index. The results of this study show that accurate prediction of milk production performance must be based on knowledge of both dairy cow genotype and feed environment.

\section{CONCLUSIONS}

Strain of HF, FS, parity, and the interaction of strain and FS had a significant effect on the milk production of spring-calving cows in pasture-based systems. The data shows that in a grass-based system, aggressive selection for increased milk production (HP strain) in the North American HF has resulted in an animal with higher milk production, and greater response to additional concentrate supplementation but with greater loss of BW and BCS postcalving. The NZ strain selected on a grass-based system for increased fat and protein yield in a given volume of milk had the lowest milk volume, highest milk composition, poorest response to concentrate, lowest BW, and highest BCS. The HD strain was intermediate for milk production and composition, had the highest BW, and was intermediate for BCS. The existence of strong interactions between strain of $\mathrm{HF}$ and FS for milk production demonstrates that the optimum strain of HF will vary with system of milk production. These results show that the prediction of animal performance must be based on knowledge of both feed system and genotype.

\section{ACKNOWLEDGMENTS}

This study is part of a joint project between Dexcel (New Zealand), Massey University (New Zealand), and 
Teagasc (Moorepark, Ireland). We acknowledge the support of Colin Holmes (Massey University). The authors acknowledge L.I.C. for sponsoring the New Zealand embryos. We thank the staff of Curtins farm for their co-operation, care, and management of the experimental animals.

\section{REFERENCES}

Bargo, F., L. D. Muller, J. E. Delahoy, and T. W. Cassidy. 2002. Milk response to concentrate supplementation of high producing dairy cows grazing at two pasture allowances. J. Dairy Sci. 85:17771792.

Berry, D. P., F. Buckley, P. Dillon, R. D. Evans, M. Rath, and R. F. Veerkamp. 2003. Estimation of genotype $\times$ environment interactions, in a grass-based system, for milk yield, body condition score, and body weight using random regression models. Livest. Prod. Sci. 83:191-203.

Boettcher, P. J., J. Fatehi, and M. M. Schutz. 2003. Genotype $\times$ environment interactions in conventional versus pasture-based dairies in Canada. J. Dairy Sci. 86:383-404.

Broster, W. H., J. D. Sutton, J. A. Bines, V. J. Broster, T. Smith, J. W. Siviter, V. W. Johnson, D. J. Napper, and E. Schuller. 1985. The influence of plane of nutrition and diet composition on the performance of dairy cows. J. Agric. Sci. (Camb.) 104:535-557.

Buckley, F., P. Dillon, M. Rath, and R. F. Veerkamp. 2000. The relationship between genetic merit for yield and live-weight, condition score and energy balance of spring calving HolsteinFriesian dairy cows on grass-based systems of milk production. J. Dairy Sci. 83:1878-1886.

Buckley, F., K. O'Sullivan, J. F. Mee, R. D. Evans, and P. Dillon. 2003. Relationships among milk yield, body condition, cow weight and reproduction in spring-calved Holstein-Friesians. J. Dairy Sci. 86:2308-2319.

Clancy, M. J., and R. K. Wilson. 1966. Development and application of a new chemical method for predicting the digestibility and intake of herbage samples. Pages 445-452 in Proc. 10th Int. Grassland Congr., Helsinki, Finland. Valtioneuvoston Kirjapaino, Helsinki, Finland.

Coulon, J. B., and B. Remond. 1991. Variations in milk output and milk protein content in response to the level of energy supply to the dairy cow: A review. Livest. Prod. Sci. 29:31-47.

Dechow, C. D., G. W. Rogers, and J. S. Clay. 2002. Heritabilities and correlations among body condition score loss, body condition score, production and reproductive performance. J. Dairy Sci. 85:3062-3070.

Delaby, L., J. L. Peyraud, and R. Delagarde. 2001. Effect of the level of concentrate supplementation, herbage allowance and milk yield at turn-out on the performance of dairy cows in mid-lactation at grazing. Anim. Sci. 73:171-181.

Dillon, P., and S. Crosse. 1997. Current and potential production in a profitable dairying system. Pages 2-33 in Proc. Teagasc Natl. Dairy Conf., Cork, Ireland.

Dillon, P., S. Crosse, G. Stakelum, and F. Flynn. 1995. The effect of calving date, and stocking rate on the performance of springcalving dairy cows. Grass Forage Sci. 50:286-299.

Evans, R. D., F. Buckley, P. Dillon, and R. F. Veerkamp. 2002. Genetic parameters for production and fertility in spring-calving Irish dairy cattle. Irish J. Agric. Res. 41:43-54.

Evans, R. D., P. Dillon, F. Buckley, M. Wallace, V. Ducrocq, and D. J. Garrick. 2004. Trends in milk production, fertility and survival of Irish dairy cows as a result of the introgression of HolsteinFriesian genes. Page 53 in Proc. Agric. Res. Forum, Tullamore, Ireland. M. G. Diskin, Teagasc, Athenry, Ireland.

Falconer, D. S. 1990. Selection in different environments: Effects on environmental sensitivity (reaction norm) and on mean performance. Genet. Res. 56:57-70.
Harris, B. L. 1998. Breeding dairy cattle for economic efficiency: A New Zealand pasture-based system. 6th World Congr. Genet. Appl. Livest. Prod., Armidale, Australia. 25:383-386.

Harris, B. L., and E. S. Kolver. 2001. Review of Holsteinization of intensive pastoral dairy farming in New Zealand. J. Dairy Sci. 84(Suppl. E):E56-E61.

Hutchings, N. J. 1991. Spatial heterogeneity and other sources of variance in sward height as measured by the sonic and HFRO sward sticks. Grass Forage Sci. 46:277-282.

Irish Cattle Breeding Statistics. 1999. Irish Cattle Breeding Federation (ICBF), Bandon, Co. Cork, Ireland.

Kennedy, J., P. Dillon, L. Delaby, P. Faverdin, G. Stakelum, and M. Rath. 2003. Effect of genetic merit and concentrate supplementation on grass intake and milk production with Holstein Friesian dairy cows. J. Dairy Sci. 86:610-621.

Kennedy, J., P. Dillon, P. Faverdin, L. Delaby, F. Buckley, and M. Rath. 2002. The effect of cow genetic merit for milk production on response to level of concentrate supplementation in a grass based system. Anim. Sci. 75:433-445.

Kolver, E. S. 2001. Rethinking our approach to lactation. Pages 3347 in Dairy Farming Annual. Inst. Vet. Anim. Biomedical Sci., Massey Univ., New Zealand.

Kolver, E. S., A. R. Napper, P. J. A. Copeman, and L. D. Muller. 2000. A comparison of New Zealand and overseas Holstein heifers. Proc. N.Z. Soc. Anim. Prod. 60:265-269.

Lohuis, M. M., and J. C. M. Dekkers. 1998. Merits of borderless evaluations. Proc. 6th World Congr. Appl. Livest. Prod., Armidale, Australia. XXVI:169-172.

Lowman, B. G., N. Scott, and S. Somerville. 1976. Condition scoring of cattle. Rev. ed. East of Scotland College of Agric., Bull. No.6. The Edinburgh School of Agriculture, Edinburgh, UK.

Morgan, D. J., G. Stakelum, and J. Dwyer. 1989. Modified neutral detergent cellulase digestibility procedure for use with the "fibretec" system. Irish J. Agric. Res. 28:91-92.

O'Donovan, M. 2000. The relationship between the performance of dairy cows and grassland management on intensive dairy farms in Ireland. Ph.D. Thesis, University College Dublin, Ireland.

Pryce, J. E., R. J. Esselmont, R. Thompson, R. F. Veerkamp, M. A. Kossaibati, and G. Simm. 1998. Estimation of genetic parameters using health, fertility and production data for a management recording system for dairy cattle. Anim. Sci. 66:577-584.

Pryce, J. E., and R. F. Veerkamp. 2001. The incorporation of fertility indices in genetic improvement programmes. BSAS Occasional Meeting-Fertility in the High Producing Dairy Cow, Galway, Ireland. Br. Soc. Anim. Sci. Publ. 26:237-249.

Rauw, W. M., E. Kanis, E. N. Noordhuizen-Stassen, and F. J. Grommers. 1998. Undesirable side effects of selection for high production efficiency in farm animals: A review. Livest. Prod. Sci. $56: 15-33$.

SAS Institute. 2002. User's Guide: Statistics. SAS Institute, Inc., Cary, NC.

Snedecor, G. W., and W. G. Cochran. 1980. Statistical Methods. 5th ed. Pages 329-393. The Iowa State Univ. Press, Ames, IA.

Sutter, F., and D. E. Beever. 2000. Energy and nitrogen metabolism in Holstein-Friesian cows during early lactation. Anim. Sci. 70:503-514.

Tilley, M. A., and R. A. Terry. 1963. A two-stage technique for the in-vitro digestion of forage crops. J. Br. Grassl. Soc. 31:69-72.

Tyrell, H. F., and J. T. Reid. 1965. Prediction of the energy value of cows' milk. J. Dairy Sci. 48:1215-1233.

Van Soest, P. J., R. H. Wine, and L. A. Moore. 1966. Estimation of the true digestibility of forages by the in-vitro digestion of cell wall. Pages 438-441 in Proc. 10th Int. Grassl. Congr., Helsinki, Finland. Valtioneuvoston Kirjapaino, Helsinki, Finland.

Veerkamp, R. F., P. Dillon, E. Kelly, A. R. Cromie, and A. F. Groen. 2002. Dairy cattle breeding objectives combining yield, survival and calving interval for pasture-based systems in Ireland under different milk quota scenarios. Livest. Prod. Sci. 76:137-151.

Veerkamp, R. F., G. Simm, and J. D. Oldham. 1994. Effects of interaction between genotype and feeding system on milk production feed intake, efficiency and body tissue mobilization in dairy cows. Livest. Prod. Sci. 39:229-241. 